\title{
Designing a library management system for Gazi Husrev-beg library using data structure and algorithm
}

\author{
Israa Al_Barazanchi ${ }^{1 *}$, Haider Rasheed Abdulshaheed ${ }^{2}$ \\ ${ }^{1,2}$ Baghdad College of Economic Sciences University, Baghdad, Iraq \\ ${ }^{1,2}$ Faculty of information and communication technology, Universiti Teknikal Malaysia Melaka, Melaka, Malaysia
}

*Corresponding author: israa44444@gmail.com

(C) The Author

2020.

Published by

ARDA.

\section{Introduction}

\begin{abstract}
Islamic manuscripts, documents, and religious books go way back in the early ages. These have been preserved at Balkans in the library named Gazi Husrevbeg, Library in an extensive manner. The premises are situated in the vicinity of a mosques complex called Sarajevo where the massive collection is articulated and catalogued in a brand new manner. It has a rich database in learning the Ottoman Empire and more specifically the Balkans in precision. The library was officially started in 2014 stating to be a state-of-art for the aspirers, researchers, historians, archeologists and every enthusiast as well as for general public. This research paper is devised in order to formulate a structure for library management system that can help preserve the age old assets like books, manuscripts, journals, articles, DVDs, etc. Everything is electronically managed and stored in a peculiar format. In order to keep a note on the entire system, the structure is beneficial to students, professors, librarians, public visitors etc. The process of issuing a given entity (book, or journal, or manuscript or anything from the library) and returning is kept a digital track and predefined penalty is cited to the individual if the returning of entity is late, or damaged, or misplaced. To maintain this procedure in a manual format might be confusing and tedious. To overcome the stress of maintaining this manually, a data structure is prepared, and algorithms are formed to get access of the library from multiple places of Gazi Husrev-beg Library.
\end{abstract}

Keywords: Gazi Husrev-beg Library, Library Management System, Data Structure

There are several libraries containing manuscripts, books, articles etc. related to Islamic world but the collection of Gazi Husrev-beg Library is amalgamated with aggregations of thousands of books, manuscripts, Sufi lodges, papers of various madrasah ${ }^{1}$, and private libraries from past several years. The present structure was designed and constructed by famous $16^{\text {th }}$ century benefactor called Sarajevo- the eponymous Gazi Husrev-beg. The primary startup was done with a madrasah, mosque, hanikah ${ }^{2}$, and a market that actually grew. The entire structure inscribes countable tombs and a famous clock-tower showcasing lunar time zone. Even though Eugene of Savoy razed Sarajevo in 1697, allegedly terminating different sorts of books,

\footnotetext{
${ }^{1}$ Islamic school.

${ }^{2}$ Monastery for dervishes.
} 
manuscripts, ledgers in the procedure. Meanwhile the madrasah was found to be endowed with a group of minority sector having books, and hence built a separate section in 1863 as renewed madrasah. Two similar projects were going on the line as sighted by Sarajevo but are found to be missing. This process was dragged unnoticed until $20^{\text {th }}$ century when the collection of books started and a new library was into consideration to build and preserve the ones that are lost and endangered. The catalogue was proposed in 1963 for the first time and then its subordinate volumes continued in a chain over the years. These books and valuables were hidden in the time of war from 1991-1994 in personal homes, bank safe-vaults, and highly confidential places to preserve the literature. This fated the collection of Oriental Institute's collection that was believed to be lost in the time of war and was destroyed in the fire created by shelling of Serbian area. The modernized for of library was finally established in January 2014 with beautiful buildings and built due to the massive donations given by a Qatari Royal Family. To create a new range of old literature, al-Furqan Foundation lead a major role and a manual version was created. The library is upgrading since then and recently it was advised to bring the entire collection in a digitalized format for the new generations. To manage the inventory of thousands of books, manuscripts, journals, articles and much more a centralized system is devised as a prototype. This prototype is devised in an effective and intricate way by using data structures and algorithms in order to devise a centralized software. All the operations related to managing of inventory and exchange of books, journals, articles, DVDs etc. between the library and any individual is operated from a single unit [1].

\section{The Collection of Gazi Husrev-beg Library}

The library into consideration had an extensive collection of Islamic literature, books, manuscripts, confidential documents, legitimate courtroom records and indigenous photos of interiors of regional sectors. The extended library consisted of 10500 volumes of primitive manuscripts in variegated languages like Arabic, Turkish, Bosnian and Persian. Arabic and Persian are found to be predominated and were apparently preserved by Sarajevo in 1697. The collection is rich in distinguished authors, speculative topics, and content rich copies from $18^{\text {th }}$ and $19^{\text {th }}$ century. The collection is apparently higher than the aggregated collection of moralistic, sermon-like, dogmatic content than the several manuscripts that are collected. The collection is segregated in a way that is easier for the researchers to extract from a vast array of literature that was condemned in a tomb stone for decades. There is a widespread collection of numerous manuscripts that are rewritten by madrasah pupils. They were exemplified by the rich culture and treaties that imparted wisdom and educational benefits. The section was covered with Ottoman Empire and the regional origins of uncountable events that are scripted in various books. The mere glimpse of ancient era is a significant sector that is covered with the help of this library. The intellectuality of researchers has crossed the bars of threshold and have a complete access to Islamic literature. The treaties consist of prayers and moralistic incitements that is a boon to many readers. The very collection is rich in Bosnian section for the travelers from Syria, Istanbul and Hijaz. The ancient essence of literature is preserved and secluded in a confined zone with a proper structure [3].

With the above mentioned collection of a massive source of knowledge, the library is also rich in literature of the Balkans from the early ages. There are around 25 thousand treaties available in Arabic language along with Turkish and Bosnian. There are 35 thousand books in Bosnian language and several supplements scripted in Latin language.

The Ottoman period is the most significant period of its time and major collection is brought through this time to the library system. The comprehensive collection is rich with court records called sijillatin the name of Sarajevo and the collections from subordinating vicinities namely Mostar, Fojnica and Tuzla [4]. The main era that supported the inventory is from 1707 to 1852 giving marvelous works from that era. The records backdated before 1707 are considered to be destroyed and elapsed from the history. In between years' records are found and preserved them backdated in 1551-52, 1556-58 and 1565-66. The Mostar takes the space of register containing data from 1766-69, Fojnica covers 1763-69 and a small part of registered data from 17th 
century in the name of Tuzla. There are around 1600 endowment charters called vakufnama ${ }^{3}, 500$ copies of $^{2}$ individual documents along with 1,100 copies consisting the court record called defters ${ }^{4}$. Added to this list, there are nearly 5,000 documents introduced by the section of Ottoman bureaucracy. The regular library customers refer these documents as an aid to the digital copies [5,6].

2.1. Lastly, the library consists of a special amalgamation of documented version of the "Muslim community" of Bosnia. This community is archived from the years 1882-1993. They have a complimentary collection of 5000 photos, posters and postcards from that era. The library is rich in present day collection of literature formulated in $19^{\text {th }}$ century depicting Sarajevo. Below are some of the Manuscripts from the library of Gazi Husrev-beg Library in Sarajevo [7].

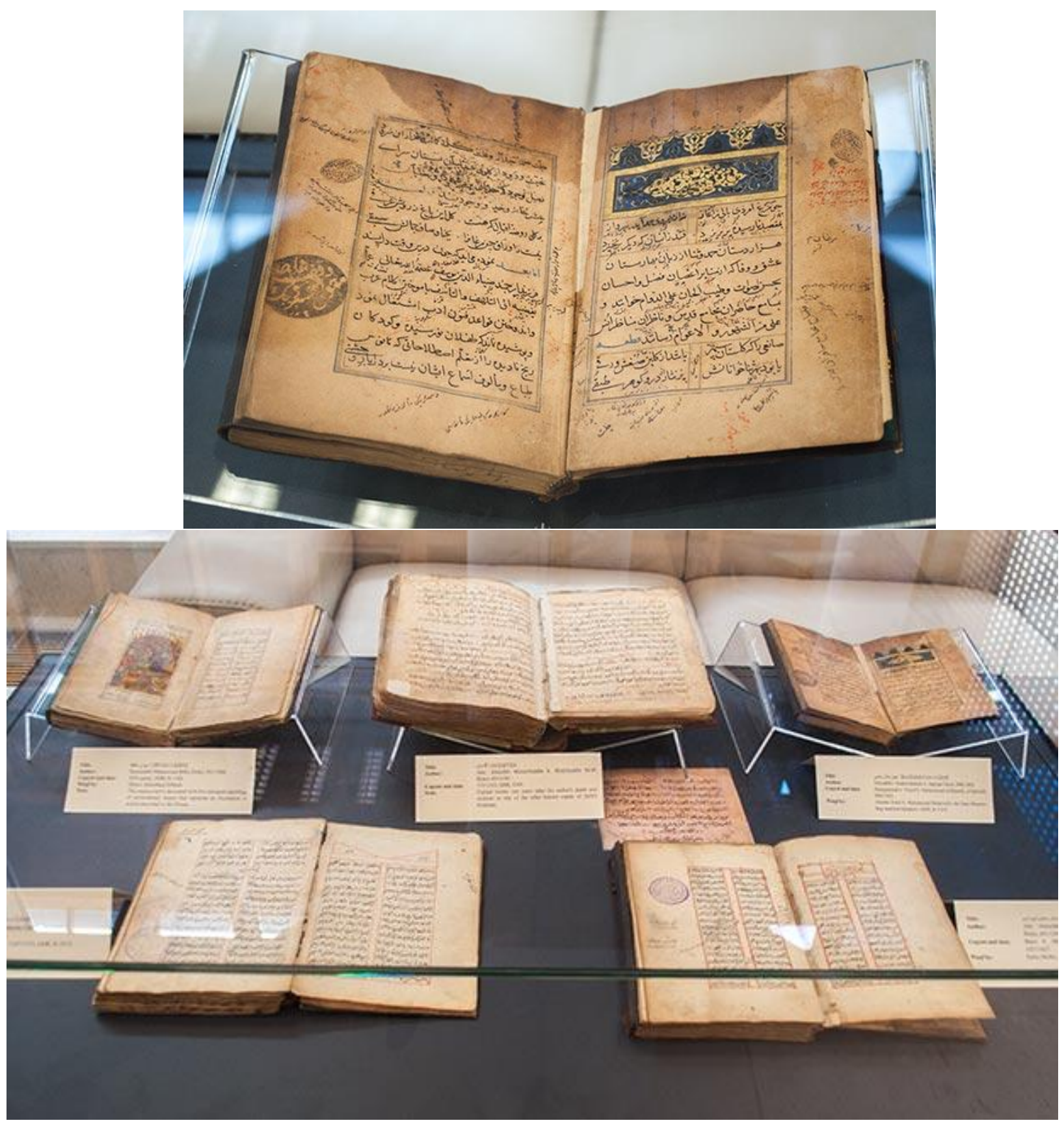

${ }^{3}$ The legacy document of a good intended for social purposes.

${ }^{4}$ Type of tax register and land cadastre in the Ottoman Empire. 
Figure 1. Manuscripts from the library of Gazi Husrev-beg Library in Sarajevo [2]

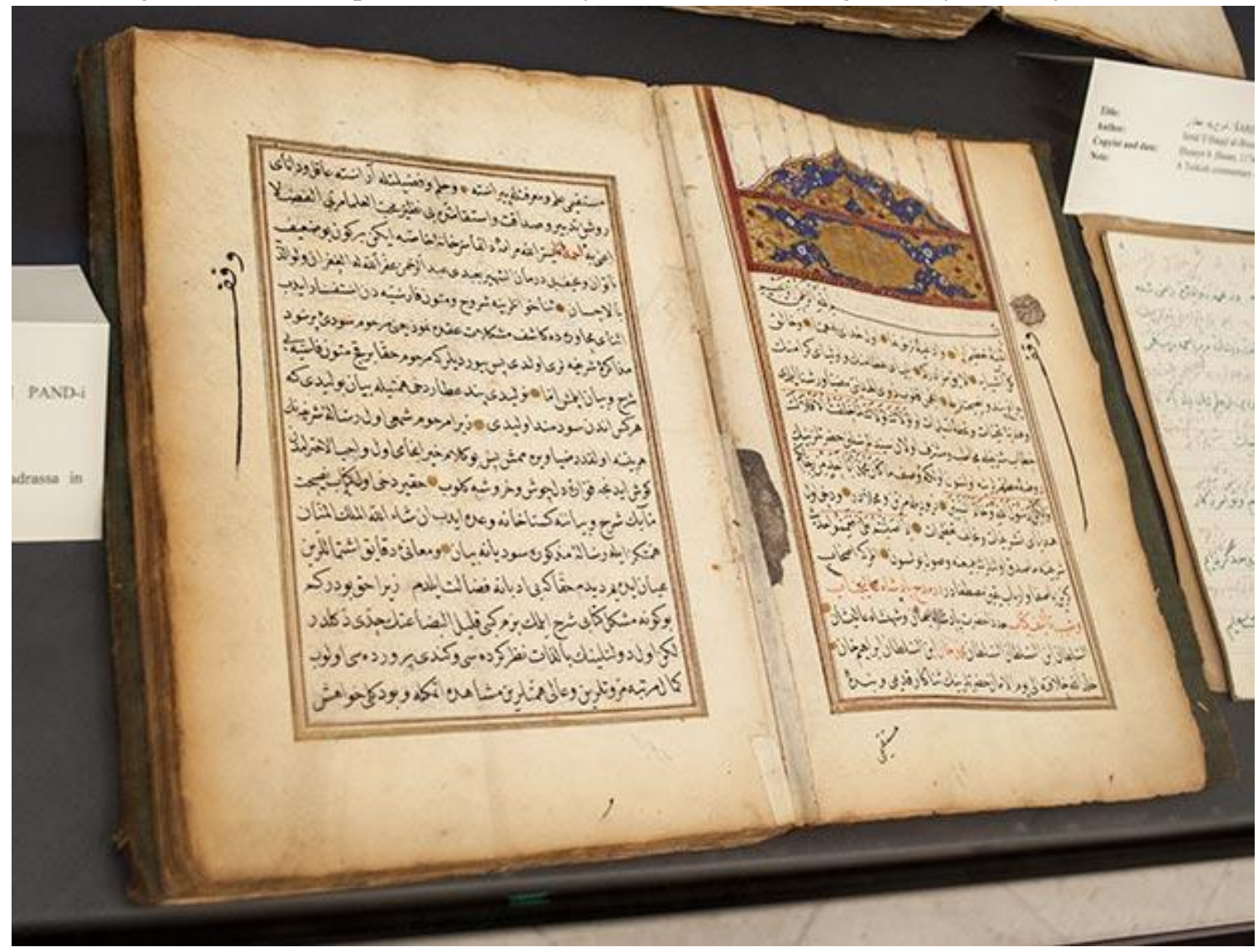

Figure 2. Manuscripts from the library of Gazi Husrev-beg Library in Sarajevo [2]

\section{The structure of data in library system}

The structure devised for creating a library system must be user friendly with less complexity and time efficient for its customers. To reduce the complexity of system, data structures are used. They are of two types:

- Primary: This is specific to particular entity that has the ability to save a given volume of data such as Boolean, Integer, Float etc. The most basic form of data structure.

- Abstract: The complex structures that are unable to be stored in the form of primary data are included in this. Linked list, Tree, Graph, Stack, Queue etc. The selection is dependent on the type of data to be inserted in the data structure.

A definite set of instructions or logic, written following a particular method, in order to achieve a couple of tasks that are primarily defined, this is called an algorithm. A particular logic for a particular operation can also be called an algorithm. An algorithm is just a code or a part of an entire program. Insertion sort, merge sort, quick sort, etc are functions that are used by programmers to develop or design library management system.

Library Management System - A library management system is planned for Gazi Husrev-beg Library which would provide access to a big database of books from various authors, offline and online journals, articles, newsletters, etc. The institute is located at two different geographical locations, Melbourne and Sidney. The students of both the campuses should have uninterrupted access to the online portal and the access to the physical library. Total of 700 students from both the campus will have access to the library system considering their academic purposes. Out of these, 300 students are VET level and 400 students are from the higher education category. Apart from these students, access to the library also needs to be given to academic 
and professional staff. Overall the total number of professionals is 20 and the count of academic staff is 40 . The access to them is given as they will need it to prepare for their lectures and exam papers. The database of this library system needs to have about $10000+$ journals and articles, on various different subjects in order to cater to all of them. Apart from this, the library needs to maintain 60 ebooks and books on each subject. Access to audio/video files also needs to be given to all the users that would be helpful for them to look for information on a particular subject. For this, it is important for the library to maintain a set of 4 DVDs for each subject.

\section{There are certain specific requirements listed below}

Tracking System - The assets of the library like journals, books, magazines, DVDs, etc., issued needs a proper system to track them. Manual tracking becomes highly impossible; hence a strong automated tracking system is needed.

Book Search Classification - Each item of the library needs to be classified by assigning an item code/barcode. Subject wise, author wise, title wise and publication wise classification is also required.

Adding and Updating Books - A new book needs to be added to the library database without any hassle and so should be the case when a new version of an old book is added.

General/Student User login - To have the items issued from the library, the students and other professionals need to register their accounts using the library card. Only registered individuals will be allowed to issue items from the library.

Admin Login - Administrator login needs to have special privileges. Adding, removing, updating, tracking of books and other related functions needs to be performed using the admin login only.

Check-in and check-out - The system should have a user-friendly interface where all the users should be able to check-in, check-out, search items from the library, etc. without any hassle.

Report generation - Total books issued, no. of books in the inventory, total books returned, total books not returned, etc., such reports should be generated using the admin logins only.

Item Real-time tracking - The items issued from the library should have a proper real-term tracking system. Books not returned on a timely basis needs to be re-issued or fine needs to be paid and students should be notified for every action taken.

Books Issued - An individual should not be allowed to hold /issued more than 4 books at any given point of time. If more time is needed, then they should be re-issued.

Pre-booking - Students can put a request to the librarian (admin) to order for a particular book that is not present in the library. Once the book is available, it can be immediately issued to the student who had put the request and then to the students if it was pre-booked.

Order for new books - At times of the unavailability of a particular book, students can place a request to the librarian so that he/she can make the book available.

Events - The system should have a separate event page where all the updates of the events happening or going to happen can be updated.

Cloud storage - The entire system needs to be made available for students from two locations so the entire database should be cloud-based.

\section{There are certain components on which the library system should be based on:}

Admin - One of the major components of the system means the librarian, will have all the permissions and access to the entire system. The admin will be responsible for accepting requests for new books, tracking/reissuing of books, fine calculation on books that have not been returned, etc. This individual will have a thorough knowledge of the entire system.

Items - This particular object will involve all the journals, books, articles, newsletters, DVDs, etc. that are either electronically present on the cloud database or physically present in the library.

System - This is the most primary part which is capable of running the online interface of the library system. It holds all the information regarding books issues, total books in the database and in the physical library, fine calculation, and stores the information of all the users of the system. 
Users - The authorized individuals, who have the privilege to use the offline and online library system. The personal data like no of books helps, identification number, contact details, etc are allocated.

The operations that will be done by the entire system:

- A login page is needed for the users to login. A separate login page is required for the admins to login as the access types for both the users is different.

- New registrations are done, and new objects added to the system.

- All the outdated or rarely used items need to be separated and flushed out of the system.

- The members should be able to use an advanced level search option so that it becomes a little convenient for the users to borrow and return the books.

- An option to park/reserves the book if the book requested by the user is not available currently.

The system needs to generate a reminder message to the user and the admin if the returning date of the book has crossed and the books need to be re-issued.

\section{Research methodology}

The library management system is designed for the Gazi Husrev-beg Library comprising of a library with books, journals, manuscripts etc. from Islamic culture. To understand the attributes of the library system, object oriented algorithms are used to simplify the process. To understand the system, flow a set of algorithms are devised and to help the developing team a set of rules are decided while designing the system. The entire library, which is located in Gazi Husrev-beg Library has the capacity of more than 2000 members browsing for books, manuscripts, articles etc. from union inventory drafted on a single panel that is handled by the admin department.

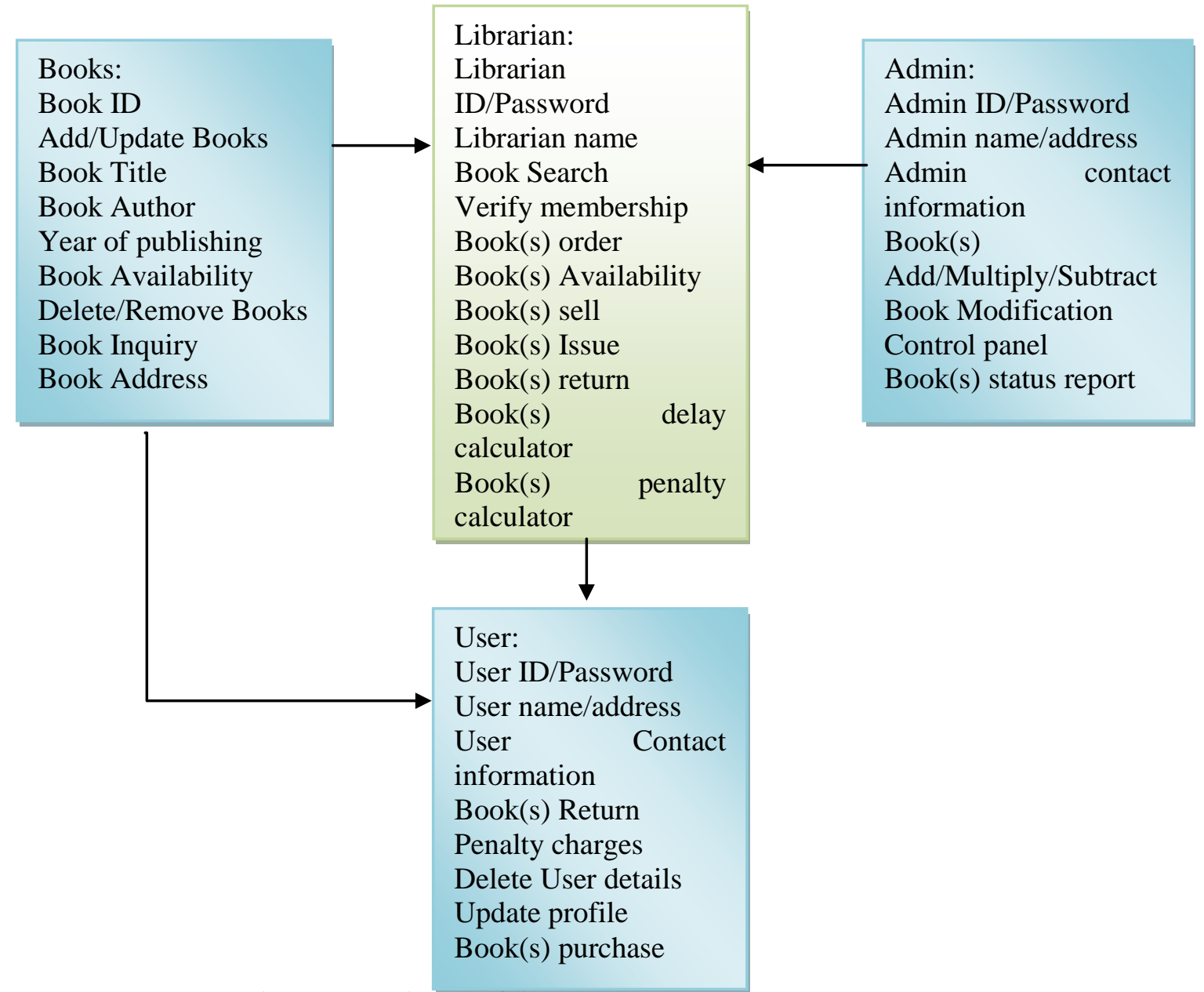

Figure 3. Designed of library management system 
Under books section, the credentials related to books are added in each row and they are distinguished based on title, author, publishing year etc. The attributes under a librarian are checking the status of the book, buying and selling of books, lending of books to users, issuing and returning of books, charging penalty to users with late submission etc. The user section involves a search panel with advanced search options, login portal, book selection/purchase/issue/return attribute, penalty column etc. The admin panel is only related with librarian attribute and it is responsible for maintaining the inventory and database of the library management system.

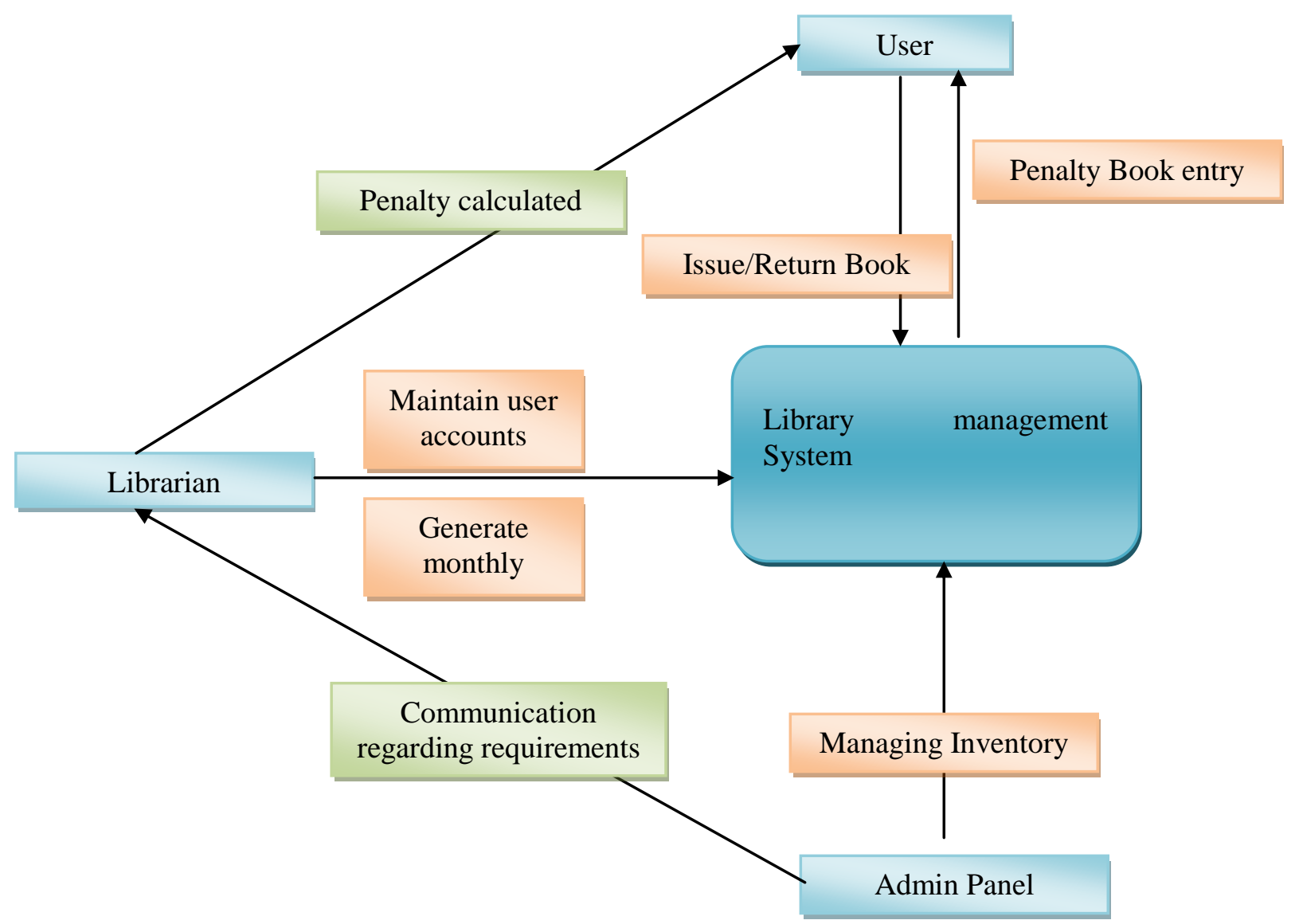

Figure 4. Data flow in the library management system

\section{Results}

The library database for Gazi Husrev-beg Library is created so that students and professionals from two different campuses can access it. The proposed system should be able to handle a large amount of data and should be able to provide seamless service. Every individual is provided with a user ID that is unique, and it is to be used to register on the system for first time users. The university has

\section{Changes to be made}

- The admin needs to be extra careful when processing in the backend for new enrolments and renewal of the existing users.

- The total number of books, journals, magazines, newspapers, articles, DVDs needs to increase to cater to all the students.

- The number of days that an individual can hold the book should be reduced.

- The total number of books that a user can hold at a given point of time should be reduced to 2 . 
- The objectives that are involved to make the system needs to be updated with a few more attributes to enhance the overall system.

- The publication details of all the books should be kept updated.

\section{Conclusion}

It is concluded that by using a database structure and an algorithm it is easy to design a library management system that has a user-friendly interface. It is observed that through minor modifications in the present library management system, a larger scale of the management system is designed for a library of Gazi Husrev-beg Library.

\section{References}

[1] University of Sarajevo, "GAZI HUSREV-BEY'S LIBRARY." [Online]. Available: https://www.unsa.ba/en/about-university/unsa-sarajevo/gazi-husrev-beys-library, Accesed October 11, 2019.

[2] "Najavljujemo svečanu promociju Monografije Gazi Husrev-begove biblioteke," Gazi Husrevbegova br. 46. [Online]. Available: http://www.ghb.ba/eng, Accesed October 11, 2019..

[3] B. Sabljaković, "60 godina od osnivanja DBBiH," BOSNIACA - Časopis Nacionalne i Univerzitetske Biblioteke Bosne i Hercegovine, (14), pp. 118-123, 2009.

[4] M. Hrasnica, Arhitekt Josip Pospišil : život i djelo, Arhitektonski Fakulteta, Bosnia 2003.

[5] S. Gacanin, "Libraries as the Islamic Cultural Heritage in Bosnia-Herzegovina"/Bosna-Hersek'te İslami Kültür Mirası Olarak Kütüphaneler, Nüsha - Journal of Oriental Studies (44), 173-182, 2017.

[6] T. Paić-Vukić, "Extant Private Libraries of Oriental Manuscripts from Bosnia: Research Possibilities", GAMER, I, 1 pp. 143-154, 2012

[7] E. Osmančević, "Ghazi Husrev-Beg by Behija Zlatar", Journal of Balkan Libraries Union, 3 (1), pp. $5-6,2010$. 